\title{
Parramatta Girls: a review of the Riverside Theatre and the relevancy past events still have in contemporary Australia
}

\author{
Georgina Stortenbeker \\ University of Technology Sydney, Faculty of Arts and Social Sciences, PO Box 123, Ultimo NSW \\ 2017, Australia. georgina.b.stortenbeker@student.uts.edu.au
}

DOI: https://doi.org/10.5130/nesais.v4i1.1519

Feminism and issues of violence against women are at the forefront of the contemporary world. However, although women are speaking out for themselves, there are still minority groups whose voices remain unheard. With the recent Women's Marches and International Women's Day, it is important to place emphasis on the mistreatment of all women throughout Australian history, particularly that of Aboriginal women, who have often had issues which have been ignored by the government and media. The Riverside Theatre (Parramatta Girls 2014) acknowledges the voices of Aboriginal women in their production of Alana Valentine's Parramatta Girls (2007), a verbatim-style play that tells the true stories of women who grew up in a training home for girls. Through the plot device of memory, an integral theme throughout the performance, eight women meet in the old Parramatta Girl's Home at a reunion, reflecting on their experiences they each had with each other and their determination to escape and survive the psychological, physical and sexual abuse inflicted on them as young girls.

The building itself became the Parramatta Girl's Home in the late nineteenth century where young girls were sent if they were considered to be at risk of moral danger, were ruled as troublesome or uncontrollable, or had been orphaned or were children of the state. The home had a long history of incarcerating Aboriginal girls under the pretence of education and training (Sullivan 2017, pp. 86). Valentine's (2007) inspiration for Parramatta Girls came from witnessing an Aboriginal woman revisiting the home and recounting the abuse she received from an institution that she had thought would protect her. From this story, Valentine compiled testimonies from various women who had the same or similar experiences and created an outlet for women, Indigenous and non-Indigenous, to voice a part of Australian history that had been untold and ignored for decades (Education at Riverside 2014). In a character list of only eight, Kerry (Sharni McDermott), Coral (Christine Anu) and Marlene (Tessa Rose) are the three that represent the Aboriginal women forced into the home in the late nineteenth and twentieth centuries.

Director Tanya Goldberg's (Parramatta Girls 2014) vision for The Riverside Theatre's production not only stayed true to the words presented by Valentine (2007) and the original stories, but also beautifully illustrated the emotional abuse that continues to haunt the women daily, shedding light on 
the topic of the ongoing effects of mental and physical abuse. The other themes exposed in the production included the notions of truth, trust and mistrust, and survival, which are presented through the small cast and their characters. The production moved the entire audience with the detailed retelling of the sexual and physical abuse that the young girls in their teens were forced to endure. For example, the aforementioned theme of survival went hand-in-hand with the exchange of sexual favours and rape for a cigarette, or sometimes even a meal. These events happened decades ago, and the play itself turned ten years old last year. Why then, does it remain so relevant to contemporary Australian society?

In a time when women are speaking for themselves and changing the way for future girls, it remains difficult for some women to voice their experiences or stand up to gain justice for wrongdoings. This is particularly the case for Australian Indigenous women and young girls, whom are often still victims of physical and sexual abuse. Data from the Australian Bureau of Statistics (2017) reveals that from 2010 to 2016, cases of sexual assault had decreased by 20\% for Aboriginal and Torres Strait Islander people. Although this is an improvement, the cases of sexual violence against Aboriginal and Torres Strait Islander people and non-Indigenous Australians has a dramatic difference, with a ratio of 1,002 Indigenous victims of sexual assault per 100,000, compared to 341 non-Indigenous victims per 100,000 (Australian Bureau of Statistics 2017). These numbers are also only including data from New South Wales, Queensland, South Australia and the Northern Territory (Australian Bureau of Statistics 2017). It is also important to note that these statistics are based off recorded crime, and cases of assault and abuse, particularly that of a sexual nature, often go unheard or unrecorded.

Throughout the play, from the set design and lighting to the emotion shown through the actions of the cast, it became obvious that the institution was used more like a prison rather than an education and training home, with the girls living there often being referred to as 'inmates' (Riverside Theatre 2014). Sullivan (2017) conducted research of a similar nature to Valentine's (2007) compilation of testimonies, using interviews to deeply understand the experiences of Indigenous women in the Parramatta Girl's Home. The interviewees in this research paper agreed with the recounts of the women represented in Parramatta Girls (Riverside Theatre 2014) being abused physically, sexually, emotionally and with everlasting effects on themselves and their families, confirming the idea of the home being more like a prison (Sullivan 2017, pp. 86-90). This research paper also describes experiences of Aboriginal girls being treated as inmates from the first moment upon stepping into the home, forcing girls to strip down and undergo medical exams to check if they were virgins (Sullivan 2017, pp. 86-90).

Today, the incarceration rates for Indigenous girls are still a problem in Australia, with $65 \%$ of girls in detention being Indigenous, and Indigenous girls being $27 \%$ more likely to be imprisoned than nonIndigenous Australians (Amnesty International 2017). Furthermore, the previously mentioned abuse suffered by victims of Parramatta Girl's Home that has been demonstrated in Parramatta Girls (2014) remains a common experience for young Aboriginal girls being held in detention today (Amnesty International 2017). Indigenous girls in detention are relating to the same practices of abuse that have been used in the past, with Aboriginal girls and women not having a voice on this issue and the media and government avoiding the problem (Amnesty International 2017). Although Parramatta Girls (2014) was produced to give a voice to the women of the nineteenth century who suffered extreme 
abuse under the Australian Government's Parramatta Girl's Home, the play continues to reflect the lives of many Aboriginal girls who are incarcerated or put into detention today.

Aside from the Aboriginal justice issues that are reflected in the play, Parramatta Girls (2014) is worth seeing if only to gain better understanding of Australia's history, particularly considering that Parramatta Girl's Home closed down in 1974, only forty-three years ago (Education at Riverside 2014). It is also an aspect of history that has been ignored by the government and the media, and in today's society, all over the world, issues of physical and sexual abuse by guardian and authoritative figures against children have been flooding the news. The violation of a child's trust is therefore a more predominant issue and is something that is clear in The Riverside Theatre's (2014) production.

Parramatta Girls (2014) excellently captures the harrowing feeling of the institution through its set design, using a minimalist and bleak beige wall to portray those of the still-standing home. The feelings of mistrust and a need for fresh air and survival was felt throughout the audience, and the right combination of music and silence was enough to send shivers down spines. The performances of the actresses will not be forgotten quickly, giving faces to the true stories of many women and children who have and continue to suffer.

The Riverside Theatre (2014) effectively and emotionally shows not only the trauma caused to the young girls in the Parramatta Girl's Home, but also the ongoing psychological torture that has remained with them since arriving there in the first place. The stories of each woman represented in the production emphasises the importance of giving minorities a voice in recounting Australian history. Parramatta Girls (2014), although recounting events that happened decades ago, remains as relevant today as it was eleven years ago when Valentine (2007) first published the verbatim piece, as issues that were once thought to be in the past continue to plague Australia. Sexual and physical abuse is still an incredibly large problem faced by Indigenous women and girls, and the violation of these young girls in detention and prison institutions is still ignored by the government and media. It is for these reasons that Parramatta Girls (2014) is a must-see for all Australian women and anyone seeking a raw perspective of an untold history. The only advice for those who will see a production of Parramatta Girls in the future ... bring the tissues.

\section{References}

Amnesty International 2017, Indigenous Girls at Risk in Detention, Broadway, New South Wales, viewed 30 ${ }^{\text {th }}$ April 2018, < $\underline{\text { https://www.amnesty.org.au/indigenous-girls-risk-detention/> }}$

Australian Bureau of Statistics 2017, 4510.0 - Recorded Crime - Victims, Australia, 2016, Canberra, Australian Capital Territory, viewed 30th April 2018, $<\underline{\text { http://www.abs.gov.au/ausstats/abs@.nsf/Lookup/by\%20Subject/4510.0 2016 Main\%20Features }}$ Victims $\% 20$ of $\% 20$ Crime, $\% 20$ Indigenous $\% 20$ Status $\sim 5>$

Education at Riverside 2014, Parramatta Girls by Alana Valentine, Riverside Theatre, Parramatta, viewed 30" ${ }^{\text {th }}$ April 2018, <https://riversideparramatta.com.au/wp-content/uploads/Parramatta-GirlsTeachers-Notes-2014.pdf $>$ 
Parramatta Girls 2014, play, written by A. Valentine, performed by The Riverside Theatre, directed by T. Goldberg, March 2014, Riverside Theatres, Parramatta.

Sullivan, C. 2017, 'Aboriginal inmate experiences of Parramatta Girls Home', Australian Aboriginal Studies, pp. 84-97.

Valentine, A. 2007, Parramatta Girls, Currency Press, Sydney.

(c) (i) (c) 2018 by the author(s). This article is distributed under the terms and conditions of the Creative Commons Attribution license (http://creativecommons.org/licenses/by-nd/4.0/). 